\title{
Researches on phosphorus
}

\section{M.P. Thenard}

To cite this article: M.P. Thenard (1848) Researches on phosphorus, Philosophical Magazine Series 3, 32:213, 153-155, DOI: 10.1080/14786444808645950

To link to this article: http://dx.doi.org/10.1080/14786444808645950

$$
\text { 册 Published online: } 30 \text { Apr } 2009 .
$$

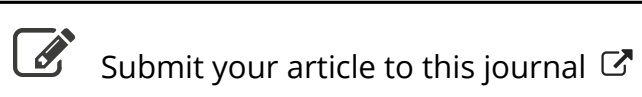

\footnotetext{
Џll Article views: 4
}

Q View related articles ¿ 
alcohol, and more so in ether. It boils at about $185^{\circ} \mathbf{F}$; but this point is not fixed, and rises gradually. M. Bouis found this liquid, cleared as much as possible from chloride of carbon, to consist of, carbon 12.36-11.57-12.35; chlorine $81 \cdot 80-80 \cdot 42-81 \cdot 63$; nitrogen $4 \cdot 9-5 \cdot 1$. M. Bouis deduces the formula $\left[\mathrm{C}^{10} \mathrm{~N}^{*} \mathrm{Cl}^{22}\right]$, which appears to $\mathrm{M}$. Gerhardt to be rather complicated.

Lastly, when nitric acid is added to the liquid $A$, and the mixture is slightly heated, it boils and emits torrents of gas, which cause the apparatus to fly to pieces. Nitrogen and carbonic acid are disengaged, and much nitrous vapour is formed, mixed with yellowish vapours of a very strong odour. Distillation gives sesquichloride of carbon $\mathrm{C}^{9} \mathrm{Cl}^{6}$, and also a very volatile colourless liquid $\mathrm{C}$, the odour of which is more irritating than that of the preceding products. M. Bouis found in the liquid $\mathrm{C}$, carbon $10.26-10.9$; chlorine $75.86-75.74$; nitrogen $8 \cdot 21-7 \cdot 85$. He represents these numbers by the formula $\left[\mathrm{C}^{6} \mathrm{~N}^{4} \mathrm{Cl}^{14} \mathrm{O}^{2}\right]$, which require carbon 10.9 ; nitrogen 75.5 ; oxygen $4 \cdot 9$.

M. Gerhardt observes that, supposing hydrogen to exist in this compound, the formula would be $\mathrm{C}^{9} \mathrm{~N}^{2} \mathrm{H} \mathrm{Cl}^{7} \mathrm{O}$; carbon 10.9 ; hy. drogen 0.2 ; nitrogen $8 \cdot 1$; chlorine 75.5 .

M. Gerhardt remarks that the preceding formulæ are not deducible in a simple manner from the composition of cyanides and water; the substance $B$ appears to be specially inadmissible. M. Bouis supposes sesquichloride of carbon to pre-exist in these compounds, and sets out from this hypothesis to explain the formation of it.-Journ. de Pharm. et de Ch., Octobre 1847.

\section{FRIGORIFIC MJXTURE.}

It is stated by M. B. F. Jourdan, that when a mixture is made of equal weights of commercial hydrochloric acid and finely-powdered sulphate of zinc, the cold produced sinks the thermumeter from $50^{\circ}$ to $20^{\circ} \mathrm{F}$.-Ibid. Janvier 1848.

\section{RESEARCHES ON PHOSPHORUS. BY M. P. THENARD.}

The author states that in the last researches which he presented to the Academy, he announced that by passing hydrochlorate of methylene over phosphuret of calcium at a high temperature, five different products were obtained, all of which were new, and all phosphorized, and which vaporized and condensed in receivers, three in a solid state and two liquid; that the three solid products, entirely formed of phosphorus, hydrogen and carbon, were especially worthy of particular attention; that one of them is a powerful alkali, the properties and probable composition of which he had described; and that the most remarkable of the three, which is spontaneously inflammable, and has an odour analogous to that of cacodyl, is converted, under the influence of acids, into a certain quantity of the two others.

The author also added, that if it were true that the alkali was represented in its composition by I equivalent of phosphorus, 9 of 
hydrogen, and 6 of carbon, $\mathrm{PH}^{9} \mathrm{C}^{6}$, it was probable that the two other liquids were represented, one by 1 equivalent of phosphorus, 6 of hydrogen and 4 of carbon, $\mathrm{PH}^{6} \mathrm{C}^{4}$, and the other by 2 equivalents of phosphorus, 3 of hydrogen and 2 of carbon, $\mathrm{P}^{\mathrm{a}} \mathrm{H}^{3} \mathrm{C}^{2}$; that is to say, that the three compounds of phosphorus and hydrogen, $\mathrm{P}^{2} \mathrm{H}, \mathrm{PH}^{2}, \mathrm{PH}^{3}$, combine, the first with one equivalent of methylene, the second with 2 , and the third with 3 .

M. Thenard states, that being desirous of submitting his views to the test of experiment, he prepared, not without danger, the new products which he wished to examine.

The analysis of the new alkali was frequently repeated, as also of the inodorous and non-alkaline matter, into one of which the spontaneously inflammable substance is transformed : the formula of the first is $\mathrm{PH}^{3}, 3 \mathrm{C}^{2} \mathrm{H}^{2}$, and of the second $\mathrm{P}^{2} \mathrm{H}, \mathrm{C}^{2} \mathrm{H}^{2}$. After having thus verified his first conjectures, the author was occupied exclusively with the spontaneously inflammable liquid. The examination was beset with difficulties, owing to the disagreeable qualities of the compound, and its unstable and inflammable nature.

The formula of this compound was found to be $\mathrm{PH}^{2}, 2 \mathrm{C}^{2} \mathrm{H}^{2}$. Its properties are, that it is a transparent liquid, colourless and slightly viscid, insoluble in water, and has an excessively disagreeable odour; it boils at about $482^{\circ} \mathrm{F}$. When exposed to the air it inflames spontaneously; but when kept in a bottle into which air is gradually introduced, it absorbs oxygen slowly, and is converted into a beautiful, very acid crystalline product.

With hydrochloric acid gas it exhibits the most important phænomena. It forms at first a solid monohydruchlorate, which is crystallized and very permanent, and afterwards passes to the state of bihydrochlorate, which is liquid and of slight stability; and if the action of the acid continues, it is uniformly transformed into hydrochlorate of the alkali $\mathrm{PH}^{3} 3 \mathrm{C}^{2} \mathrm{H}^{2}$, and into a yellow substance $\mathrm{P}^{2} \mathrm{H} \mathrm{C}^{2} \mathrm{H}^{2}$.

The monohydrochlorate when put into water at $32^{\circ} \mathrm{F}$. dissolves without alteration; but if the temperature be gradually raised, it decomposes at the same time as the water, so as to give rise to a new acid, which the alkali produces by oxidizement, and to a new gas which gradually combines with its volume of oxygen, and produces a liquid of strongly marked acid properties ; and it also absorbs either one or two volumes of hydrochloric acid gas, and forms fine crystals, from which water instantly disengages the new gas.

M. Thenard concludes from his experiments,-

1. 'That phosphorus combines with hydrogen and carbon in several proportions.

2. That the three phosphurets of hydrogen at present known unite, -

The solid phosphuret $\mathrm{P}^{2} \mathrm{H}$ with one equivalent of methylene ;

The liquid phosphuret $\mathrm{PH}^{2}$ with two equivalents of methylene;

The gaseous phosphuret $\mathrm{PH}^{3}$ with three equivalents of methylene; that is to say, with as many equivalents of methylene as there are of hydrogen in the phosphurets. 
3. That the first of these three new compounds is solid, yellow, inodorous, insipid, insoluble in water, and inert, at least at common temperatures; that the second is liquid, extremely noxious, spontaneously inflammable, and susceptible of forming a new acid when gradually exposed to oxygen; that the third is alkaline, non-inflammable, and susceptible, like the preceding, of absorbing oxygen gas, and giving rise to a totally different acid.

4. That the spontaneously inflammable compound may be con. verted into the two others under the influence of a great excess of acid; but in the state of monohydrochlorate it is decomposed by the action of water and of heat, producing a new gas $\mathrm{P} \mathrm{H}^{3} \mathrm{C}^{2} \mathrm{H}^{2}$, or probably $\mathrm{PH} \mathrm{C}^{2} \mathrm{H}^{2} \mathrm{H}^{2}$.

5. That this same compound is analogous to cacodyl; and confirms by this analogy the natural relations which exist between arsenic and phosphorus.

The author concludes with the following considerations:-

Is it not probable that, with other hydrochlorates of carburetted hydrogen and phosphuret of calcium, a series of products would be obtained analogous to those which are yielded by hydrochlorate of methylene?

May we not hope that the arseniurets of hydrogen will produce similar combinations; and is it going too far to presume that it will probably be the same with nitruret of hydrogen?

There would thus be formed a great number of new compounds which ought to be assimilated to organic compounds, and of which thecry now indicates the composition and properties.

It is even probable that phosphorusoccurs in cerebral matter, the nerves, \&c., in which it has been discovered in this state of com. bination; but the phosphuret of hydrogen in them must be combined with much carburetted hydrogen.

The author has already procured a new series of products resulting from the reaction of hydrochloric æther, or hydrochlorate of ethyle and phosphuret of calcium : they are such, that the series which they constitute is to that which the author has described, as alcohol is to pyroxylic spirit._Comptes Rendus, Decembre 13, 1847.

\section{ON CHRISTIANITE-A NEW MINERAL,}

M. Descloizeaux states that in the month of July 1846 , he found in the cavities of an amygdaloidal trap which forms the bay of Dyrefiord, on the western coast of Iceland, some small translucent colourless crystals, which scratched glass readily, were fragile, and of sp. gr. $2 \cdot 201$.

These crystals are very closely aggregated together, and, grouped in the mammillary form or that of cock, s-combs, analogous to some varieties of prehnite, have as their primary form a right rhombic prism of $111^{\circ} \cdot 15^{\prime}$, in which one of the sides of the base is to the height as 537 to 786 . 